\title{
A PÁLYAÉRDEKLŐDÉS KIALAKÍTÁSÁNAK FONTOSSÁGA AZ ISKOLAI MUNKÁBAN
}

\author{
TUDLIK CSILLA \\ Eszterházy Károly Egyetem \\ Neveléstudományi Doktori Iskola
}

A tanulmány a szakirodalmat hívja segítségül, hogy feltárja a pályaérdeklődés kialakításának fontosságát az iskolai munkában. Az érdeklődés sokféle definíciója megmutatja a jelenség vonásjellegét, a környezettel való kapcsolatát és motivációs funkcióját. Számos kutatás bizonyította, hogy a kialakult pályaérdeklődés hatással van személyes, tanulási és munkahelyi jóllétünkre, ezért vizsgálat alá vettettük a nemhez, a tanulmányi eredményességhez és a pályaválasztási bizonytalansághoz füződő viszonyát. Áttekintettük az iskolai pályaedukációra gyakorolt befolyását, s végül javaslatokat fogalmaztunk meg az iskolai munkára vonatkozóan.

\section{Miért éppen az érdeklődés?}

Minden ember eljut a pályadöntés fázisába. Egyeseknek könnyen megy, másoknak segítség kell hozzá. A jó pályadöntést alapvetően a személyiségvonások, a képességek, a pálya- és munkaerőpiaci ismeretek és a lehetőségek kiegyensúlyozott kombinációja biztosítja. Életünk során ma már nem egy pályaválasztási pontról beszélünk, sokkal inkább egy folyamatról, amelynek lehetnek elágazásai. A folyamatot karriernek vagy életpályának nevezzük, mely hangsúlyozza az életkorokon átnyúló (az iskoláskoron messze túlmutató), főként az egyén döntési pontjaiban fokozódó támogatást és a személyiség, a tanuló egyéni pszichés fejlettségéhez alkalmazkodó életpálya-menedzselési kompetencia fejlesztését (Borbély, 2010, 8.). Az életpályát - és benne az egy vagy több döntési pontot - akkor tudjuk hatékonyan segíteni, ha feltárjuk az egyénre jellemző pilléreit. Többféle pályamodellel igyekeztek a terület kutatói leírni, mely összetevők járulnak hozzá az optimális pálya kiválasztásához. Egyes elméletek a pályaalkalmasságot hangsúlyozzák az egyén képességeit sem előtt tartva (Parsons), mások több vonás dinamikájában látják a megoldást (Holland), míg a fejlődéselméletek (Super) a megfelelő idő megtalálását tarják fontosnak, a modern elméletek (Lent-Brown-Heckett, 
Savickas, Patton-McMahon) pedig a környezet befolyásoló hatását említik. Valamennyiben azonban hangsúlyosan jelenik meg a pályaérdeklődés mint meghatározó tényező.

Tanulmányunkban - a szakirodalom áttekintésével - arra keressük a választ, hogyan hasznosíthatja az iskola az érdeklődésről szerzett ismereteket. A jelenség nem véletlenül áll a kutatások középpontjában, hiszen ami érdekel, azt szívesebben és kedvvel csináljuk, általa a cselekvés sikerélményhez juttat, elégedettséggel tölt el, gyorsabb a tanulás, és kitartóbb az egyén a feladatokban. Emellett a tanulási motivációban és ezen keresztül a lemorzsolódás megakadályozásában sokkal nagyobb szerepe van az érdeklődésnek, az értékeknek, mint a „mérni” kívánt kompetenciáknak, amelyek képességeknek tűnnek, hiszen ezek fejleszthetők. (Borbély-Fazakas-Juhász, 2019) Az érdeklődés ma már bizonyítottan hatással van a személyes, a tanulmányok és a munka világával kapcsolatos jóllétünkre. Jelentős az irodalma annak a gondolatnak, hogy a pályák felfedezéséhez és megismeréséhez kapcsolódó tevékenységeket az érdeklődés indítja el, majd ez olyan viselkedéssort generál, amely direkten reflektál az egyén teljesítményére a munka világában. Az érdeklődés számos teljesítménykritériumot előre jelez mind a munkahelyi, mind az oktatási környezetben. Schmidt (2014) több teória összeolvasztásával létrehozta az egyéni különbségek integrált modelljét, melyben azt állítja, a specifikus érdeklődés a specifikus tudáson és készségeken kívül a felnőtt személyek tanulmányi és munkahelyi teljesítményét is meghatározza. A hatás akkor a legerősebb, ha a tanulmányok és a munkahely megválasztása egyaránt tükrözi az érdeklődési területet. Bouchard (1997) Valla és Ceci (2011) és Ceci és mtsai. (2009) nyomán ugyanakkor úgy véli, az érdeklődés részben genetikailag meghatározott, különösen a férfiak prenatális hormonszintje befolyásolja a tárgyak iránti elköteleződésüket. Többen is arra jutottak vizsgálatukban, hogy az általános kíváncsiság az intelligencia és a személyiségvonások mellett a „harmadik pillére” az iskolai teljesítménynek (von Stumm és mtsai., 2011; Chamorro-Premuzic, Furnham és Ackerman, 2006; Furnham, Monsen és Ahmetoglu, 2009), és az érdeklődés határozza meg, hogyan tud élni az egyén az intellektuális potenciáljával. A pályaérdeklődés összességében tehát pozitívan befolyásolja a szakmai eredményeket (Almeida, Ahmetoglu és Chamorro-Premuzic, 2014, Vardarlı, Özyürek, Wilkins-Yel és Tracey, 2017, Volodina és Nagy, 2016), a munkahelyi elégedettséget (Vock, Köller és Nagy, 2013), a lehetséges munkahelyváltást (van Iddekinge, Roth, Putka és Lanivich, 2011), és szerepet játszik a hosszú távú foglalkoztatási minták kialakulásában (Wille és mtsai., 2014). Már 1913-ban Dewey (idézi Nye és mtsai., 2012, 90.) a következőképpen írt: „az érdeklődés az azonosulást jelzi a cselekvéssel, összekötvén az egyén vágyát, törekvését és gondolatát a céllal, amelyben a cselekvés végződik, és az eszközzel, amely által véghezviszi”. Hasonlóképpen fokozza az erőfeszítést a tanulásban és a munkahelyi fejlődésben, ahogy erre már több kutatás is rávilágított (Renninger, Hidi és Krapp, 1992, van Iddekinge és mtsai, 2011, Vroom és Deci, 1992). Ezen kívül a motiváció tartósságát is 
jelzi az érdeklődés, vagyis segít fókuszálni a kitűzött célra, és fenntartani a figyelmet annak eléréséig (Allen és Robbins, 2010, Webb, Lubinski és Benbow, 2002). E három jellemző (irány, lendület, tartósság) segíti a tanulmányi és munkateljesítmény fejlődését.

\section{Az érdeklődés természete}

Super (1995) úgy definiálta az érdeklődést, mint tevékenységek iránti preferencia, amelytől az egyén szükségletei és értékei kielégítését reméli; Crites (1999) pedig preferenciát jelölő egyéni különbségként jellemzi; illetve az egyénből kedvelést, elutasítást vagy indifferens érzést kiváltó munkapszichológiai megfogalmazással is találkozunk (Betsworth és Fouad, 1997, Hansen, 1984). Holland (1997) érvelése szerint a pályaérdeklődés az egyén személyiségének fontos kifejeződése, amely a személy motivációjára, tudására, személyiségére és képességeire reflektál. Izard és Ackerman (2000) szerint az érdeklődés motiválja a felfedezést és a tanulást, és ez garantálja az egyén környezete iránti elköteleződését, amely a túléléshez és az adaptációhoz szükséges. Szilágyi (2007) megfogalmazása szerint ezen tulajdonságunk által választjuk ki környezetünkből a számunkra fontos tárgyakat, személyeket és tevékenységeket. Chamorro-Premuzic (2015) úgy tartja, az érdeklődést a személyiség és a pályadöntés közötti kapcsolatként is leírhatjuk. Több kutató is hasonlóképpen vélekedik, amikor azt írják, hogy a pályaérdeklődés tevékenységek, környezetek és eredmények vonásszerủ preferenciája, amely speciális viselkedésen és attitűdön keresztül motiválja a célkitűzést (Rounds, 1995, Su, Round és Armstrong, 2009, Su, Stoll és Rounds, 2019). Van Iddekinge, Putka és Cambell (2011) egy viszonylag stabil egyéni különbségként jellemzi a pályaérdeklődést, amely bizonyos munkatevékenységek és környezetek iránti preferencián keresztül befolyásolja a viselkedést. Az érdeklődés fontos ösztönzője a kognitív képességek fejlődésének és a tudáselsajátításnak, hiszen általa választjuk ki a számunkra érdekes tanulási környezeteket, és motivációt lelünk a tanulásra (Päessler és mtsai., 2015, Denissen, Zarrett és Eccles, 2007, Su és Nye, 2017). A pályaérdeklődés vonásszerü preferencia tevékenységek iránt, vagy olyan kontextus iránt, amelyben a tevékenység megvalósul, vagy kedvelt tevékenységekhez társuló eredmények iránt, amely célorientált viselkedést motivál, vagy bizonyos környezet felé irányítja az egyént (Rounds és Su, 2014). Ez a preferencia nem egyszerűen az élmény megtapasztalása, hanem hosszan tartó figyelem az érdeklődés tárgyára, egyfajta kíváncsiság és kitartó belefeledkezés akár komplex vagy meghökkentő feladatokba és tevékenységekbe (Silvia, 2008, Turner és Silvia, 2006). Az érdeklődés a belső motiváció forrása, amely az emberi viselkedés, tudáselsajátítás és teljesítmény irányát, erejét és tartósságát jelzi (Su és Nye, 2017). Az érdeklődés nemcsak személyiségjegy, amely jellemzi az egyént, hanem kapcsolat az egyén és a külvilág között. 
Su, Stoll és Rounds (2019) ugyanakkor továbbra is úgy látják, a fenti megfogalmazások továbbra sem adnak választ arra, hogyan alakul ki a preferencia az egyénben, mi dönti el, kedves-e számunkra az adott dolog, miért helyezünk valamit előbbre, mint a többit, van-e látens jelentése a válaszainknak, illetve változik-e idővel az érdeklődés. Korábbi kutatásokat áttekintve megkülönböztetik a szituációs érdeklődést mint pszichológiai állapotot, amely egy feladat vagy környezet által generált pillanatnyi kíváncsiság (Ainley, 2007, Hidi és Renninger, 2006, Krapp, 2007, Silvia, 2006), a diszpozíciós érdeklődéstől vagy hajlamtól, amely az egyén által preferált tevékenységekben és környezetekben mutatkozik meg (Ackerman és Heggestad, 1997, Holland, 1959, 1997, Lubinski, 2000, Savickas és Spokane, 1999, Rounds és Su, 2014). Előbbi az érdeklődés eredetét és funkcióját, míg utóbbi a fejlődését és megtapasztalását jelzi. Összességében mindkét látásmód az érdeklődés tárgyának fontosságát hangsúlyozza, nemcsak az egyén egy jellemzőjeként tekint az érdeklődésre, hanem mint a környezetéhez füződő viszonyra, és kiemeli az érdeklődés kapcsolatát a motivációval, tanulással és teljesítménnyel mind az oktatási, mind pedig munkakörnyezetben.

Izard (1977, idézi Silvia 2001, 2008) gondolata szerint az érdeklődés először egy pozitív kötődés, amely kellemes érzést vált ki az érdeklődés tárgya vagy a feladat iránt, így az egyén többet szeretne megtudni róla, részesülni akar ismét az érzésből. Az érdeklődés azonban különbözik más pozitív érzéstől, mint az öröm vagy elégedettség, inkább kíváncsiságról van szó, amely az érdeklődés tárgyára vagy feladatára irányuló működésnek a kezdete, nem pedig a vége. Az érdeklődés, még ha érzelmi állapotot idéz is elő, az értelemhez kötődik, leszűkíti az észlelési mezőt, koncentrálja a figyelmet, és elmélyíti a kognitív feldolgozást. Schiefele (2009) úgy jellemzi az érdeklődést mint értékhitek összessége, amely folyamatos kognitív feldolgozást igényel, és környezetben aktiválódva direkten hat az egyén belső motivációjára. Emellett jelentőséget, érdemet tulajdonítunk az érdeklődés tárgyának és annak, mennyire áll közel az egyén énképéhez (Super, 1963). Vagyis egyrészt azt vizsgálja az egyén, mennyire érdekes számára az érdeklődés tárgya, másrészt jelent-e valamit számára, kompatibilis-e a magáról alkotott képével és szerepével. Gottfredson (2005) példája szerint ezen a szinten dől el, hogy egy lány, bár erősen érdeklődik a számítástechnika iránt, mégis elutasítja a területet, mivel társadalmi szerepével nem összeegyeztethető. Az egyéni beállítódás az alapja annak, milyen affektív és kognitív reakciókat ad az egyén egy bizonyos helyzetben, kedveli-e általában például a művészeteket vagy sem. Su, Stoll és Rounds (2019) szerint az érdeklődés a külső környezet tárgyainak és tevékenységeinek absztrakt reprezentációja, mint például a matematika, a tanítás vagy a pénzügyek. Úgy tartják, mivel vonásjellegről van szó, nem szükséges folyamatosan aktiválni ahhoz, hogy fenntartható legyen az érdeklődés. Ahogy több vizsgálat megmutatta (Krause és Clark, 2014, Rohe és Krause, 1998), az érdeklődés azoknál a sérült (például gerinctörést szenvedett) embereknél 
is megmarad, akik már nem tudják az érdeklődési körbe tartozó tevékenységet végezni. Úgy hiszik, az érdeklődés a kognitív és nem kognitív jellemzők közötti kapocs, és az egyéni különbségek különböző aspektusainak kombinációja (értékek, képességek, motiváció) teszi a munka és élet eredményeinek nagy hatású előrejelzőjévé.

Számos kutatás fókuszába került az érdeklődés stabilitásának és változékonyságának vizsgálata (Hoff, Briley, Wee és Rounds, 2018, Low, Yoon, Roberts és Rounds, 2005, Roberts és DelVecchio, 2000, Roberts, Walton és Viechtbauer, 2006). Low és mtsai. (2005) metaanalitikus vizsgálatukban megmutatták, hogy a pályaérdeklődés viszonylag stabil különböző életszakaszokon keresztül. A pályaérdeklődés mint az egyén és környezete közötti összhangot elősegítő tényező jól detektálható fiatalkortól a felnőttkor közepéig, még olyan korcsoportnál is (16 év alatt), amelyben az érdeklődés mérése várhatóan nem ad pontos eredményt. Azt találták, hogy körülbelül 12 és 40 éves kor között az érdeklődés sokkal stabilabb képet mutat, mint a személyiségvonások. Tracy, Robbins és Hofsess (2005) azt is megerősítették, hogy az érdeklődés átlagos szintje a fiatalkor alatt növekszik, Donnay és mtsai. (2005) pedig rámutattak, hogy a 18 éves korra kiforró érdeklődés a következő két évtizedre meghatározóvá válik. Az általános iskolások érdeklődési szerkezete különleges, preferenciáikat a nem és a hely szerint (iskolában vagy iskolán kívül) szervezik (Tracey és Ward, 1998). Tracey (2002) vizsgálata szerint a gyerekek érdeklödése az általános iskola és középiskola átmeneti időszakában élesen esik, különösen a lányok tárgyias és kutató érdeklődése esetében. A Holland-féle tipológia ${ }^{1}$ csak a középiskolai szakaszban kezd kialakulni, s onnantól kezdve az érdeklődés struktúrája keveset változik kilencedik és tizenkettedik évfolyam között (Darcy és Tracey, 2007). Ville és mtsai. (2014) azt is bizonyították, hogy a nem moderátor lehet az érdeklődés alakulásában. A kutató, művészi, szociális és vállalkozói érdeklődés mindkét nemnél erősödött a vizsgált korosztályban, és a legnagyobb változás a középiskolából a felnőttkorba való átmenetben jelentkezett, a konvencionális érdeklődés (a rendezettség, szervezés, világos feladatok, gyakran irodai tevékenységek iránti vonzódás) ugyanezen időszakban nőknél emelkedett, míg a férfiaknál csökkenést mutatott. Hoff és mtsai. (2018) szerint fiatalkorban szinte valamennyi Holland-féle érdeklődési típus átlaga csökken, majd az érettségi és a felsőoktatás kezdete körül visszaáll, sőt a fiatal felnőttek emberekkel kapcsolatos tevékenységei fokozatosan erősödnek (például a szociális, vállalkozói típusok esetében). Értelmezésükben ez annyit tesz, hogy amikor az ember változik, érdeklődése megjósolható módon módosul, és ez fordítva is igaz (Hoff és mtsai., 2020).

Stabilitása ellenére a felnőtt munkavállalókra is igaz, hogy szakmai érdeklődésük formálódik az idők során. Az egyén olyan munkahelyet keres, amely illeszkedik érdeklődéséhez és

1 Az embereket és a munkakörnyezetet hat típusba sorolta: tárgyias (realista), kutató, művészi, közösségi (szociális), vállalkozó, végrehajtó (konvencionális). 
ez alapján a tapasztalatához, ám ha időközben kiderül, hogy a hely nem teljesen váltotta be a hozzá füzött reményeket, a munkavállaló a szervezeten belül keres személyiségéhez jobban illeszkedő területet vagy tevékenységet (Roberts és Wood, 2006). Az is előfordul, hogy a munkakörnyezet hatására az egyén érdeklődése alakul át, szélesedik ki annak érdekében, hogy a munkahellyel való egyezés teljesebb legyen (Low és mtsai., 2005). Mindkét eset arra világít rá, hogy a munkaterülethez való illeszkedése hiánya elégedetlenséghez, negatív munkateljesítményhez vezet, vagy a szervezet elhagyására kényszeríti a dolgozót, vagyis a karrierváltók motivációját az erőteljesebb egyén-munka megfelelés generálja (Donohue, 2006).

\section{Az érdeklődés és egyes változók kapcsolata}

\section{Az érdeklödés és a nem}

A nemek kérdése a pályaérdeklődés kapcsán régóta foglalkoztatja a kutatókat. Mustata (2014) középiskolás mintájában nem talált bizonyítékot arra vonatkozóan, hogy a pályaérdeklődés nemi befolyás alatt állna. Need és de Jong (2002, idézi Klapwijk és Rommes, 2009) holland fiatalok mintáján is azt állapította meg, hogy a nők csak enyhén érdeklődnek jobban a vállalkozói lét és a szociális tevékenységek iránt. Jelentősebb azonban annak az irodalma, hogy létezik nemi eltérés a pályaérdeklődésben. Több pályaválasztási elmélet detektálta (Holland és Prediger egyaránt), hogy a fiúk erősebben vonzódnak a tárgyak iránt, míg a lányok az emberi kapcsolatokban jobbak. Gottfredson (1981) teóriája szerint azok a nemi különbségek, amelyek alapján az egyén eldönti, mely foglalkozás illik férfiakhoz és nőkhöz, nagyon korán kódolódik a munka világáról alkotott kognitív térképünkbe. A gyerekek folyamatosan olyan képekkel találkoznak a külvilágból, amelyek az egyes nemek számára elfogadható szakmákat jelenítik meg, s ezek olyan szinten belsővé válnak, hogy észrevétlenül irányítják a maszkulin és feminin karrierekről alkotott véleményünket. Bár később ez a kognitív térkép finomodik a beáramló információk által, de alapjaiban már nehezen változtatják meg a nemi különbségtételt. Su, Rounds és Armstrong (2009) 47 különböző érdeklődésmérő kérdőív használati útmutatóját vetette össze. Azt találták, hogy a férfiak nagyobb tárgyias és kutatói érdeklődést produkáltak, mint a nők, ellenben ők a művészi, szociális és konvencionális területen értek el magasabb pontszámokat. A tárgyias és a szociális az a két érdeklödési terület, ahol a legjelentősebb a nemi eltérés az egyéb személyiségjellemzők között. Hasonló eredményre jutottak Ott-Holland és mtsai. (2013), vagyis a férfiak szignifikánsan alacsonyabb művészi, konvencionális és szociális, míg magasabb tárgyias és kutatói érdeklődésről számoltak be. Arra is felhívták a figyelmet, hogy azokban a társadalmakban, ahol a nemi egyenlőségnek nagyobb teret engednek, a művészi hajlam esetében csökkent, viszont a tudományos és egyházi területen erősödött a nemek közötti 
különbség. Ion, Nye és Iliescu (2017) 1519 résztvevőt négy életkori csoportba (12-15, 16-20, 21-30, 31-59 év) sorolt vizsgálata során. Minden, különösen a tárgyias és a konvencionális érdeklődési területen szignifikáns eltérést tapasztaltak a nemek között. Azt is megfigyelték, hogy a legfiatalabb korosztályban a legelenyészőbb a különbség az érdeklődés differenciáltsága között, a középiskolásoké pedig a legkifejezettebb, még a felnőttekhez képest is. Lawson, Leeb, Crouter és McHale (2018) szintén megerősítette, hogy a fiúk és férfiak általános iskolás és fiatal felnőtt koruk között tipikusan férfiszakmának számító területeket kedveltek vagy választottak (a lányoknál kevésbé volt jellemző a nem szerinti választás), ami azt jelzi, hogy a férfiak erősen ragaszkodnak a gyerekkorban elképzelt foglalkozásukhoz, továbbá a nők és a férfiak eltérő pályát járnak be pályafejlődésük során. Blažev, Babarović és Šverko (2019) 980 olyan végzős középiskolást követett nyomon másfél évig, akik felsőoktatási vagy munkaerőpiaci átmenet előtt álltak. A Prediger-féle kétpólusú (tárgyak vagy emberek) megközelítést használták. Megerősítették, hogy a fiúk a tárgyak, míg a lányok az emberek irányában mutatnak érdeklődést. Mindkét nemnél az érdeklődés szintje esett a vizsgált időszakban, a fiúk tárgyak iránti vonzalma erőteljesebben. Ugyanakkor a periódus végére az érdeklődés nemi sztereotipizálása enyhült. Oschnik (2020) abból a szempontból is megvizsgálta a nemi kérdést, vajon egyes nemzetek között van-e eltérés. Lengyel és szlovén csoportokat hasonlított össze, és azt találta, hogy a lengyel mintában erőteljesebb volt a nemi különbség jelenléte. A nők szignifikánsan jobban vonzódtak a szociális tevékenységekhez, míg a férfiak a vezetői képességeket igénylő pályákat preferálták. A szlovén mintában nem merült fel ilyen jelentős különbség, pusztán általánosságban a nők kevésbé vonzódtak a műszaki területekhez. Ludwikowski, Schechinger és Armstrong (2019) arra is rávilágított, hogy az érdeklődés megállapítására használt eszköz is befolyásolja a nemenkénti eredményt. Szakmákat bemutató kártyák szortírozását és kétféle Likert-skálás (szakmákat és tevékenységeket felsoroló) kérdőívet alkalmaztak állításuk bizonyítására. Azt tapasztalták, hogy a legnagyobb nemi eltérés akkor volt látható, amikor a kártyaszortírozásra került a sor, vagyis a kép alapján döntötte el a kérdezett, mivel szeretne foglalkozni. Ez azt jelzi, Gottfredson felvetése helyes, s valóban van egy előfeltevésünk arról, hogyan néz ki egy nőies és egy férfias munka. A legkisebb nemi eltérést akkor tapasztalták a kutatók, amikor pusztán tevékenységek kedveltségét jelölték a megkérdezettek. Sadler és mtsai. (2012) középiskolások pályaaspirációit vizsgálva megállapították, hogy az MTMI-pályák iránti érdeklődés megközelítőleg háromszoros a fiúknál a lányokhoz képest. Pedig a matematika és a természettudományok PISA-vizsgálati eredményeinek nemek szerinti eltérését vizsgálva megállapítható, hogy nem mutatható ki szignifikáns eltérés a fiúk és a lányok között (Ostorics és mtsai., 2016), egyes országokban a lányok eredményei voltak némileg jobbak, máshol a fiúké. A lányok megítélése önmagukról sokkal nagyobb különbséget feltételez, amit a nemi sztereotípiákat gyakran felerősítő oktatásból fakadó önbizalomhiány is okozhat (Réti, 2011; Kereszty, 2014). 


\section{Érdeklödés és tanulmányi eredményesség}

Henry (1989) Holland egyén-környezet megfelelését és a tanulmányi eredményesség kapcsolatát vizsgálta az egészségügyi területen belül. A 157 diákot Holland kérdőíve alapján kongruens vagy nem kongruens kategóriába sorolta. Azt találta, hogy a szakmai környezetükkel egyezést mutató hallgatók szignifikánsan magasabb összesített tanulmányi eredményt értek el, mint nem kongruens társaik. Schiefele, Krapp és Winterel (1992) tanulmányukban szerették volna újra felhívni a figyelmet, hogy korábban nagy hagyománya volt az érdeklődés és a tanulmányi eredmény közötti kapcsolat feltárásának, ezért 1965 előtti és utáni bontásban számba vették azokat a cikkeket, amelyek a két jellemző viszonyát írják le. Azt találták, hogy az érdeklődés és a tanulmányi eredményesség közötti valamennyi vizsgált írás megállapította az összefüggést általában 0.09 és 0.67 közötti értékben. A biológia és irodalom kivételével a tantárgyak egyenlő arányban járultak hozzá a korreláció létrejöttéhez. A korosztályok között (általános iskolás, középiskolás és felsőoktatási hallgató) nem tudtak kimutatni eltérést, vagyis nem találták bizonyítottnak, hogy az idősebbek esetében erősebb kapcsolatról beszélünk az érdeklődés és a tanulmányi eredmény között. Rámutattak ugyanakkor, hogy ha a tanulók már a pubertás alatt felismerik az iskolai tárgyakhoz kapcsolódó érdeklődésüket, akkor a tanárok és szülők becsatornázhatják ezt az érdeklődést egy produktív jövőtervezés keretébe. Az viszont világosan kitűnt vizsgálatukból, hogy a lányok tanulmányi eredménye kevésbé kötődik az érdeklődésükhöz. A szerzők ugyan nem találtak magyarázatot a jelenségre, de valószínủleg a hozzáállás és szorgalom szintjével lehet kapcsolatban az eredmény. Köller, Baumert és Schnabel (2001) német diákokat vizsgált $(\mathrm{N}=602)$ hetedik, tízedik és tizenkettedik évfolyamon az érdeklődésük és a matematikai teljesítményük kapcsolatának feltárása érdekében. Megállapították, hogy a fiúk jobb teljesítményt mutatnak a matematika terén, jobban érdekli őket, és többen választják emelt szinten a tárgyat. Az is kiderült, hogy az érdeklődésnek nincs szignifikáns hatása magára a tanulásra, a kurzusválasztásra azonban igen hetedik és tízedik évfolyamon. A magas érdeklődéssel bíró tanulók szívesebben választottak emelt szintủ kurzusokat, ami végül a jobb tanulmányi eredményben nyilvánult meg. A magas teljesítményű tanulók jelentősebb érdeklődésről számoltak be, mint a kevésbé jól teljesítők. Összességében arra hívta fel a figyelmet, hogy az érdeklődésnek az önszabályozó tanulás és a specifikáció eldöntése esetén kiemelt szerepe van. Nye, Su, Rounds és Drasgow (2012) egyetemista mintán szintén megállapították, hogy az érdeklődés és a tanulmányi eredményesség összefügg ( 0.23 szinten), akkor a legerősebb a kapcsolat, ha az egyén kongruenciát mutat a munkakörnyezetével. Az érdeklődés nemcsak a jegyekre, hanem a kitartásra is hatással van, azok a tanulók, akik tárgyuk iránt érdeklődnek, jobb jegyeket szereznek, és nagyobb valószínűséggel maradnak választott programjukban. Korábbi kutatásokkal összehasonlítva megfigyelték, hogy nem az érdeklődés szintje (mennyire kedveli), hanem az érdeklődési profil (mit kedvel) a meghatározó. Javaslatot tettek arra vonatkozóan, hogy 
a felsőoktatási felvételit az érdeklődési profil elemzésével lenne szükséges kiegészíteni, mert ez biztosíthatná, hogy a hallgató ragaszkodni fog a programhoz, kitartóbb lesz, és jobb tanulmányi eredmény tud elérni. Koreai középiskolai mintán $(\mathrm{N}=500)$ (Lee, Lee és Bong, 2014) az érdeklődés és az énhatékonyság kapcsolatát vizsgálták kutatók a tanulmányi önszabályozás és eredményesség jelenségével. Azt találták, hogy az érdeklődés a másik két változó elörejelzőjeként működik. Úgy vélték, hogy az énhatékonyság és az érdeklődés - mint két motivációs forrás - támogatásával az önszabályozó tanulás ösztönözhető. Su (2012) több mint 400.000 amerikai diák adatai segítségével vizsgálta a pályaérdeklődés és az érdeklődési kongruencia erejét a sikeres karrier elörejelzésében. A TALENT Terv az Egyesült Államokban az 1960-as években indult longitudinális vizsgálat, mely során a tanulók kognitív képességét, pályaérdeklődését, személyiségét, továbbá demográfiai és szociokulturális hátterét tárták fel napjainkig bezárólag. Su az adatok áttanulmányozása során arra jutott, hogy az érdeklődés (83,3\%-ban) a későbbi kereset legnagyobb „bejóslója”, továbbá erősen meghatározza a felsőoktatási tanulmányi eredményeket (hasonló szinten, mint a képességek), a kitartást, a diplomaszerzés esélyét és a megszerzett végzettség presztízsét. Különösen a természettudományok esetében számított az érdeklődés kongruenciája, amely jobb jegyekhez és később magasabb keresethez társult. Éppen ezért a felsőoktatási szakok esetében elengedhetetlennek tartja az érdeklődés előzetes felmérését a jó képességek mellett. Az is világosan kitűnt, hogy a megszületett gyermekek száma elsősorban a nőknél negatívan hat a fizetésre és az elnyerhető szakmai elismerésre. Ismét bizonyítást nyert, hogy az emberek-tárgyak szembenállást a nem határozza meg. Su végső konklúzióként felhívta a figyelmet arra, hogy az érdeklődés (mind a hat Holland-féle érdeklődési faktor) nem egyszerủen csak a választásainkat befolyásolja, hanem teljesítményünkre is hatással van, a disztális eredményekre (kereset, elismerés) pedig még hatványozottabban, mint a konkrét tanulmányi jegyekre.

Több metaanalízis is napvilágot látott (Schiefele, Krapp és Winteler, 1992, Schiefele, Krapp és Schreyer, 1993), amely az egyéni érdeklődés és az iskolai teljesítmény kapcsolatát vette górcső alá. Megállapításaik szerint különböző tantárgyak, iskolatípusok, életkori csoportok esetében is az érdeklődés körülbelül 10\%-ban határozza meg a teljesítményt, és a lányok tanulmányi eredményessége kevésbé kötődik érdeklődésükhöz, mint a fiúké, továbbá az érdeklődésvezérelt tevékenységek jobb eredményhez vezetnek. Czeglédi és Máth (2013) a tantárgyi attitűd és a teljesítmény kapcsolatát kutatta. Longitudinális vizsgálatukban öt középiskola 345 tanulója vett részt. Tízedik évfolyam elején és tizenegyedik évfolyam végén mérték a tanulók intelligenciáját, motivációját, tanulási orientációját és a biológia tantárgy iránti attitűdjét. Megállapították, hogy szignifikáns kapcsolat van a tantárgy iránti érdeklődés és az elért eredmények között, vagyis ha vonzó a diák számára a biológia tantárgy, jobb teljesítményre képes. 


\section{Érdeklödés és a pályaválasztási bizonytalanság}

A pályaválasztási bizonytalanság jelensége régóta a pszichológia látókörébe került, bár sokáig csak a döntéshozás egyszeri elemeként tekintettek rá. Chartrand és Robbins (1990) még úgy jellemezte a pályabizonytalanságot mint a pálya kiválasztását vagy a pályatervek megvalósítását gátló tényező. Gati, Krausz és Osipow (1996) szerint a pályabizonytalanság azokra az emberekre utal, akik pályadöntési folyamatukban problémát észlelnek. Osipow (1999) azonban arra hívta fel a figyelmet, hogy a munkaerőpiac folyamatos változásai, a munkában töltött aktív évek növekedése miatt a jelenség többször előfordul(hat) az ember életében. Megfogalmazása szerint a pályabizonytalanság egy állapot, amely felbukkan és eltűnik, amikor a döntés megszületik, megvalósul, elavul és végül új döntés meghozatalát teszi szükségessé, így pillanatnyi bizonytalanságot idézve elő. Ez azonban nem egyenlő a döntésképtelenséggel, hanem olyan vonása az embernek, amely döntéshozatali helyzetekben általánosan jelen van. Egy egyén lehet bizonytalan (akár többször is az élet bizonyos pontjain) anélkül, hogy döntésképtelen lenne. Ezt egyébként Germeijs és Boeck (2002) bizonyította is, mert skálájukkal sikerült középiskolás mintán elkülöníteni az általában döntésképtelen, illetve a választásukban bizonytalan tanulókat. Holland (1997) nyomán Osipow (1999) négy lehetséges bizonytalansági esetet sorakoztat fel:

- az egyén többféle és ellentmondásos érdeklődéssel bír,

- nincs egyetlen erős érdeklődési területe sem az illetőnek,

- túl sok érdeklődési területet kedvel az illető,

- tehetséges egyénről van szó, aki adottságai révén több területen tudna kiteljesedni.

A pályaválasztási bizonytalanság jelenségét számos változóval kapcsolták össze. Lukács (2012) középiskolás és egyetemista mintán végzett vizsgálatában kimutatta, hogy a párkapcsolatban lévő középiskolások több pályainformációt igényelnek, vagyis a másik által önmagáról kapott információ is felhasználható lehet a tanácsadás során; a végzősök esetében a legnagyobb a pályaválasztási szorongás; az iskola típusa is hatással van a pályaválasztási bizonytalanságra, illetve a szakközépiskolások kevésbé igénylik a pályákkal kapcsolatos információkat. Duffy és Sedlacek (2007) egy rendkívül nehezen megfogható jelenséget, az elhivatottságot vizsgálta háromezer elsőéves egyetemista mintáján. Azt találták, hogy a felsőoktatási szakot elhivatottságból választók (vagyis kifejezetten az érdeklődésre alapozók) határozottabbak és elégedettebbek a döntéshozatalukkal, mint a keresgélők. Hasonló eredményre jutott Rawat (2011) is, aki megerősítette, hogy a „kijelölt út” követése jobb munkaattitűdhöz, kevésbé valószínủ kiégéshez és fokozott teljesítményhez vezet. Guay és mtsai. (2003) föiskolás mintán $(\mathrm{N}=834)$ a pályaválasztási bizonytalanságot vizsgálták a szülői stílus és barátok függvényében. Azt találták, hogy mindkét változó az énhatékonyságon és önszabályozáson keresztül megjósolja a pályaválasztási bizonytalanságot. Azoknál a hallgatóknál a legalacsonyabb a hatékonyság, az autonómia és a pozitivitás 
a pályadöntési tevékenységekben, akiknél erős a szülői és baráti kontroll, következésképpen a legmagasabb a bizonytalanság szintje. Stǎricǎ (2012) a szülői támogatás és a személyiségjegyek felől közelítette meg a középfokú oktatásban részt vevők karrierrel kapcsolatos bizonytalanságát. Azt támasztotta alá, hogy a szülö segítő bevonódása növeli a diák tanulmányokat érintő önértékelését, ez pedig a pályaválasztási bizonytalanság csökkenéséhez vezet. Javasolja tehát, hogy a továbbtanulási döntésben, illetve a beavatkozási formákban vegyen részt a lehetőségekhez mérten a szülő. A nemzetközi szakirodalomban is kevés, hazánkban pedig egyértelműen hiányos a pályaérdeklődés és a pályaválasztási bizonytalanság egymásra hatásának kutatása. Feldman (2003) munkája szerint a gyakorlatias szakmák és szakok esetében, ahol egyértelmüen meghatározható a munkatevékenység, alacsonyabb a bizonytalanság, míg szociális és müvészi területen, ahol meglehetősen nagy a választék az űzhető szakmák számában és a feladatok sokszínűségében, ott nagyobb bizonytalanság tapasztalható. Korábbi kismintás vizsgálatunk (Tudlik, 2020) is arra világított rá, hogy a bizonytalanság negatív viszonyban áll azokkal az érdeklődési területekkel, amelyekben a munkafolyamatok szélesebb körben ismertek, világosak, mintánkban ilyen az agrár, az üzleti adminisztráció, a mérnöki-matematikai-tudományos területek és a logisztika világa. Ott azonban, ahol emberekkel kell együttműködni, például turizmus, kereskedelem, egészségügy, inkább a karrierdöntési énhatékonyságnak van szerepe. Bár Creed, Prideaux és Patton (2006) inkább a bizonytalanság és döntésképtelenség témakörét feszegette, s nem annyira a pályaérdeklődést, mégis tanulmányukban azt a konklúziót vonták le, hogy a döntésbe vetett hit változása nincs kapcsolatban a bizonytalanság érzésével, a két jelenség viszonyát valószínűleg egy harmadik változó, feltehetően az érdeklődés befolyásolja. Atitsogbe és mtsai. (2018) nemzetközi összehasonlításra használták az érdeklődés és a pályaválasztási bizonytalanság kapcsolatának vizsgálatát. Svájci és Burkina Fasó-beli $(\mathrm{N}=700)$ felsőoktatási hallgatók vettek részt a felmérésben, melyből kiderült, hogy csak gyenge kapcsolat van az érdeklődés differenciáltsága és konzisztenciája, valamint a pályadöntési nehézség szintje között. Értelmezésük szerint tehát az előbbi fejlődése hosszú idő alatt megy végbe, míg utóbbi egy bizonyos pillanatban jelenik meg. Továbbá az érdeklődés esetében a nemi különbségek jelentősebbek voltak mindkét országon belül, a pályadöntési nehézség szintje ugyanakkor az országok között mutatott különbséget. Az afrikai diákok érdeklődése és döntése között nincs egyértelmű kapcsolat, ugyanakkor a svájci hallgatóknál az információhiány és az érdeklődés differenciáltsága gyenge negatív korrelációt mutatott.

A bizonytalanság ugyanakkor nem feltétlenül hátráltatja a pályadöntést, hiszen ahogy Feldman (2003) megjegyezte, a kétség vezeti el a fiatalt a hatékonyabb explorációhoz és sikeresebb önmegismeréshez. Útkeresésként foghatjuk fel, vagyis az egyén több munkaterületet, tevékenységet, szakot kipróbál, mielött végleges döntését meghozná. Fontos pontokon (emelt szinten tanult tantárgy kiválasztása, felsőoktatási szak kiválasztása, munkahely keresése) 
természetes jelenség a bizonytalanság (Creed, Patton, Prideaux, 2006). Ahhoz azonban, hogy pozitívan tekintsünk rá, az szükséges, hogy a társadalom ne ítélje meg negatívan a keresgélést, hogy ne érje hátrány az elhúzódó döntésért a fiatalt.

\section{Az érdeklődés szerepe az iskolai munkában}

Herbart (idézi Finánczy, 1932, 22.) volt az első, aki „az érdeklődésre mint maradandó szellemi energiára nyomatékosan ráutalt, oly értelmezéssel, hogy ha az anyag kiszorul is idővel a gyermek tudatából, ennek az érdeklődésnek - jó oktatást feltételezve - mint ösztönző, továbbsarkalló szellemi erőnek meg kell maradnia”. Az oktatás célját a sokoldalú érdeklődés kiművelésében látta, mely sem nem egyoldalú, sem pedig szétszórt, hisz előbbi a beszűkülést, utóbbi pedig az ismeretek egységének megbontását eredményezné. Nem véletlen, hogy a pedagógiák jelentős része átvette a fenti gondolatot, könnyen felismerhető volt a jótékony hatása annak, ha a tanuló azzal foglalatoskodik, amihez kedvet érez, amiben örömét leli, ami felkelti kíváncsiságát. Talán nem túl elrugaszkodott a felvetés, hogy a pályaérdeklődés kialakításában is szerepet tulajdonítsunk az iskolának. Mivel jelen írásnak nem célja feltárni és ismertetni hazánk iskolai pályaorientációs, pályaedukációs rendszerét, ezért csak rámutatunk, hogy ez a szerep nem egységes módon működik az intézményekben, a szolgáltatások formája, időkerete, témája jelentősen eltér attól függően, milyen fókuszú az adott iskola, például továbbtanulásra készít fel, szakképzésben vesz részt, vagy általános iskoláról van szó. Suhajda (2017) munkájában csoportosította a leggyakrabban használt iskolai pályaorientációs módszereket. Eszerint az egyéni és csoportos tanácsadás, a csoportos foglalkozás, a számítógéppel támogatott információátadás, az önértékelés, a pályaismertetés, a pályaválasztási tematikus tábor, a pályaválasztási szülői értekezlet és a pályaportfólió alkotják a tanácskérő fiatalokat támogató munka gerincét. Pedagóguskutatása alapján több fontos megállapítást tett. A megkérdezettek ( N = 264) 84\%-a szerint van intézményükben pályaválasztási döntésre felkészitő tevékenység, leginkább az általános és szakképző intézményekben kap szerepet a pályaedukáció, a leggyakrabban megjelölt ilyen irányú tevékenység az osztályfőnöki óra, szülői értekezlet, nyílt nap, külső előadó meghívása, pályaválasztási nap, kiállítás, szakkör vagy külön sáv a tantervben. Az is látható, hogy az általános iskolában a középiskolás jelentkezés adminisztrációja a legmeghatározóbb, legkevésbé a gimnáziumi és a többcélú intézményi pedagógusok tudnak az intézményben működő pályaorientációról, illetve hogy a tanárok életkorának növekedésével nő a bizonyosság, hogy intézménye végez ilyen tevékenységet. Utóbbi magyarázatát a korábban jól működő megyei ellátási és pályaválasztási felelősi rendszerben látja Suhajda. Az iskolai munka jelentősége abban áll, hogy azokat az alapvető készségeket fejlessze, az önismeretre és pályákra vonatkozó információkat 
közvetítse, amelyek egy-egy foglalkozási szerephez kötődnek, méghozzá tanári segítséggel. Ahogy Ritoók (1986) megfogalmazta, a pályaválasztásnak a széles körű általános képzést követően az érdeklődés, képességek, készségek és személyiségjegyek alapján kell megvalósulnia. A pályaedukációs munkában részt vállaló tanár feladata tehát a pályaválasztási érettség fejlesztése, a döntés megfogalmazásának támogatása, a hivatástudat kialakítása és a választott területre való beilleszkedés elősegítése. A különböző iskolai beavatkozások hatékonysága bár eltérő, de létük mindenképpen támogatóan hat a pályadöntés meghozatalára. Maree (2019) kérdőívek segítségével a középiskolások csoportos karrierépítési tanácsadását vizsgálta $(\mathrm{N}=57)$. Az első beavatkozás előtt és a második beavatkozás után a Karrier-rugalmassági Skála dél-afrikai változatát töltötték ki a fiatalok, míg közben a Karrierérdeklődési Profillal és a Maree Karrier Mátrixszal dolgoztak. Azt találta, hogy az intervenció végére a fiúk és a lányok pályarugalmassága jelentősen növekedett a skála valamennyi alskálája szerint. Bár nemek szerinti különbséget nem talált, de mindkét nem pre- és poszttesztje különbséget mutatott a kontroll és az önbizalom alskála eredményeiben. Di Fabio és Maree (2013) szintén a csoportos pályaépítési tanácsadást vizsgálta. Olasz egyetemistákból két csoportot alakítottak ki, az egyik (42 résztvevő) narratív pályatanácsadásban részesült, a másik (47 fô) viszont nem. Az eredmények azt mutatták, hogy a tanácsadásban részesülő fiatalok specifikusabb élet- és pályacélokat tudtak kitűzni, csökkent a pályadöntési bizonytalanságuk, ugyanakkor nőtt é-hatékonyságuk. A hatások kimutatása nem csupán az iskolai korosztályra korlátozódik. Burns és mtsai. (2016) azt találták 20 vizsgált felnőtt körében, hogy ha a tanácsadás során életrajzokat és írásbeli narratívát használnak, az segít a klienseknek kideríteni, hogy a terveik megfelelnek-e az életstílusuknak, értékeiknek, és segítenek a jelentésteremtésben. Szabó és mtsai. (é.n.) szintén a felnőtt lakosság körében végeztek kutatást a pályatanácsadás hatékonyságáról. A mélyinterjúk során $(\mathrm{N}=45)$ hét témakörben keresték a változást: a változás élményének átélése, a tanácsadói kapcsolat minősége, a problémaelemzés, a személyes jelentés feltárása, a források és kompetenciák fejlesztése, az átkeretezés, a felmerült problémák kielégítése és nyitott kérdések. Kérdőíves eljárással $(\mathrm{N}=302)$ pedig tanácskérői csoportokat különítettek el. A csoportok leginkább az információszükséglet és a tervezési készség szintjében tértek el, ugyanakkor valamennyi csoport a támogató kapcsolatról és az életpálya-építési készségének fokozódásáról számolt be. Hárs és Tóth (2009) egyenesen a pályaorientáció gazdasági hatását vizsgálták, és úgy összegezték, hogy a helyes pályadöntés nemcsak magasabb jövedelmet eredményez, hanem rövidebb álláskeresést, állásba helyezést és egyéb pozitív makrogazdasági hozadékot is jelent. Ennek előzménye azonban, hogy a tanuló motivációjában és tanulási eredményében változás következzen be, továbbá egyáltalán részt vegyen az oktatásban.

Többen arról is beszámoltak, hogy az iskolai pályaorientáció hatékonysága kétséges. Brown és mtsai. $(2012,3$.) metaanalízisek áttekintése után úgy találták, „a döntési nehézséget 
célzó beavatkozási forma hatékony, de hatása közepes erősségü", míg Whiston és mtsai. (2017) megerősítették, hogy a pályadöntési intervenciók hatása meglehetősen gyenge, 0,21 a pályaidentitás, míg 0,40 a pályaérettség vonatkozásában. Todt és Schreiber (1998, idézi Krapp, 2002) áttekintve a kilencvenes évek érdeklődéssel foglalkozó tanulmányait arra mutatott rá, hogy általánosságban a család és a kortársak mellett az iskola hatása meglehetősen csekély az érdeklődés formálásában. Ugyanakkor ha bizonyos speciális tartalmakat vagy csoportokat vizsgálunk, jelentősége van az iskolai munkának. Häussler és Hoffmann (2002) a hetedik évfolyamos fizika kedveltségében kívántak eredményt elérni úgy, hogy enyhítsék a lányok természettudományok iránti idegenkedését. Új taneszközökkel olyan témákba ágyazták a fizikát, amelyeket valószínúleg kedvelnek a lányok. A tanév végére úgy sikerült pozitív változást elérniük a lányok fizikához kapcsolódó énképében és teljesítményében, hogy a fiúkat semmilyen negatív mellékhatás nem érte. Noack és mtsai. (2010) a német iskolarendszer alapján vizsgálták a diákok szakmák iránti explorációs kedvét, a felsőoktatásba és a nem felsőoktatásba készülő fiatalok összehasonlításával. Azt találták, hogy az utóbbi csoport, továbbá az idősebbek, illetve a lányok motiváltabbak abban, hogy felfedezzék a munka világát, és minél több szakmát, foglalkozást megismerjenek. Ahol az iskolai klíma elfogadó és nyílt volt, ott nagyobb energiákat fektettek a diákok az explorációba. Összességében tehát nem az a fontos, hogy a határidőkhöz, fejlődési fázisokhoz kössük a pályaedukációs munkát, hanem annak intenzitását érdemes a tantervbe beépíteni. Gábrity (idézi Pusztai-Szigeti, 2018) vajdasági magyarok középiskolai és felsőoktatási választásait vizsgálta. A 819 fö megkérdezett 57\%-a az érdeklődés, 14\%-a az elhivatottság, végül pedig az elhelyezkedési lehetőség szerint döntött. Vagyis a munkaerőpiaci igények ellenére olyan területet képzelnek el maguknak, amely vonzza őket. Fontos szerepe van tehát az iskolának abban, hogy a kristályosodási folyamatot elősegítse, széles látókört biztosítson, és segítsen elkerülni a túl korai specializációt. Bár a kedvelt cselekvésformák, illetve a személyek vagy tárgyak iránti alapérdeklődés fiatal életkorban nyilvánvaló válik, számítani kell arra, hogy tinédzserkor után áthelyeződnek az érdeklődés súlypontjai. A művészet, a sport és a természet iránti vonzalom kezdetben erős, de keveseknél marad meg pályacélként, ugyanakkor az emberi kapcsolatok előtérbe helyeződése csak a későbbi életkorban jelentkezik. Szabó és mtsai. (é.n.) összességében az eredményes pályatanácsadási folyamatot úgy jellemzik, hogy a tanácskérő problémájának komplexitása jelentős mértékben csökken.

\section{Speciális csoportok az iskolában}

A nemzeti köznevelésről szóló 2011. évi CXC. törvény értelmében különleges bánásmódot igényel az a tanuló, aki sajátos nevelési igényü, beilleszkedési, tanulási, magatartási nehézséggel küzd vagy kiemelten tehetséges (4. \$13.). A pályaválasztás szempontjából mindhárom kategória befolyásoló tényező lehet. Az első két esetben azokat a pályaterületeket keressük, 
ahol nem kizáró ok a sajátosság, ahol a nehezítettség kompenzálható, míg a tehetségesek esetében a legjellemzőbb, a kiteljesedést leginkább ígérő pályát járjuk körbe. A törvény egyértelmüen fogalmaz az SNI- és a BTMN-állapotok leírásakor, ugyanakkor a tehetséges tanulók jellemzése nehezen megragadható. ${ }^{2}$ A tehetségek felkarolásának bár jelentős hagyományai vannak Magyarországon, kiépített azonosító- és ellátórendszerrel nem rendelkezik. A Nemzeti Tehetség Program keretében működő mentorrendszer, elkülönült köznevelési és felsőoktatási programok és lelkes tanárok tartják életben a tehetséggondozási és -fejlesztési munkát. A kiváló kezdeményezések ellenére jelenleg még nem látható az a fajta kiépítettség (például speciális iskolák, utánkövetés vagy jogszabályok formájában), mint a sajátos nevelési igényű és a beilleszkedési, tanulási, magatartási nehézséggel küzdő tanulók esetében.

A pályaérdeklődés alapvetően nem alakul másképp a különleges bánásmódot igénylő tanulók esetében, hiszen életkor és nem szerint ugyanazokat a jellemzőket mutatják, mint tipikusan fejlődő társaik. Ugyanakkor specialitásuk okán a tanulmányi eredményekben, önismeretben, pályainformációkhoz való hozzájutásban, ezáltal a pályaválasztási bizonytalanság szintjében különbségek lehetnek a tanulók között. Plata és Bone (1989, idézi Stromberg, 2008) 15 és 18 éves tanulók esetében azt találták, hogy a tanulási nehézséggel küzdők más foglalkozási preferenciát állítanak fel, mint társaik. A szakképzést igénylő, esetleg a végzettséget nem igénylö (tehát alacsonyabb fizetéssel járó) munkákat fontosabbnak találták, mint a magas végzettséget vagy vezetői készséget igénylő területeket. Kevésbé stabil pályaaspirációval rendelkeztek, és később is többségében bizonytalanságot éltek át a pályaválasztással kapcsolatban. Ugyanakkor azt is megállapították, hogy a nehézséggel szembenézők a korai években nagyobb valószínűséggel változtatják karrierelképzelésüket az alacsonyról magas presztízsű szakmára. Rojewski (1999, idézi Stromberg, 2008) érettségi után két évig követte nyomon a fiatalokat, és azt tapasztalta, hogy a tanulásban akadályozottak kisebb százalékban szereznek diplomát (inkább érettségi utáni szakképzésben vesznek részt), viszont jellemzőbb esetükben a munkanélküliség, továbbá mindkét

$2, \ldots$ sajátos nevelési igényű gyermek, tanuló: az a különleges bánásmódot igénylő gyermek, tanuló, aki a szakértői bizottság szakértői véleménye alapján mozgásszervi, érzékszervi (látási, hallási), értelmi vagy beszédfogyatékos, több fogyatékosság együttes előfordulása esetén halmozottan fogyatékos, autizmus spektrum zavarral vagy egyéb pszichés fejlődési zavarral (súlyos tanulási, figyelem- vagy magatartásszabályozási zavarral) küzd”.

„... beilleszkedési, tanulási, magatartási nehézséggel küzdő gyermek, tanuló: az a különleges bánásmódot igénylő gyermek, tanuló, aki a szakértői bizottság szakértői véleménye alapján az életkorához viszonyítottan jelentősen alulteljesít, társas kapcsolati problémákkal, tanulási, magatartásszabályozási hiányosságokkal küzd, közösségbe való beilleszkedése, továbbá személyiségfejlődése nehezített vagy sajátos tendenciákat mutat, de nem minősül sajátos nevelési igényűnek".

„... kiemelten tehetséges gyermek, tanuló: az a különleges bánásmódot igénylő gyermek, tanuló, aki átlag feletti általános vagy speciális képességek birtokában magas fokú kreativitással rendelkezik, és felkelthető benne a feladat iránti erős motiváció, elkötelezettség”. 
nem képviselői a közepes vagy alacsony presztízsủ pályákat célozták meg feltehetően az alacsony énhatékonyság miatt. Stromberg (2008) kutatása szintén különbséget jelzett a nehézséggel küzdő és a tipikus fiatal felnőttek között. Az érdeklődés vizsgálatakor a nem tipikus fejlődésủ tanulók valamennyi skálán kevesebb számú itemet jelöltek, ami egyrészt az érdeklődés alacsony általános energiaszintjéről tanúskodik, másrészt a kompetenciák és az énkép szerény megítéléséről az alskálák szerint. A későbbiekben mindez hozzájárul ahhoz, hogy a fiatalok kevesebb olyan tevékenységben vegyenek részt, amely kívül esik a komfortzónájukon, és kisebb énhatékonyságot élnek át. Stromberg azt is megállapította, hogy a tipikustól eltérő tanulók kevésbé beszélgetnek szüleikkel a felsőoktatásról, leginkább a szakképzést és az előkészítő képzéseket ajánlják számukra. Lindstrom és mtsai. (2012) középiskolás fogyatékos lányok pályaelképzeléseit vizsgálták. Azt találták, hogy az alacsony önbecsülés, a magabiztosság, a fogyatékosság elfogadásának hiánya komoly akadályt jelent. Javaslatuk szerint az egyén erősségeire és kommunikációjára érdemes hangsúlyt helyezni, továbbá tudatosítani a fogyatékosság tényét információnyújtással. Török (2016) vizsgálatában rámutatott, hogy az SNI-tanulók pozitívabbak ugyan, de tanulmányi eredményükben, a pályákról való információk gyűjtésében és iskolai énhatékonyságban elmaradnak tipikus társaiktól. Az iskolatípus alapján különbséget talált a pályadöntési énhatékonyság szintjében, vagyis az SNI-s csoporton belül a gimnáziumban tanulók magasabb énhatékonyságot élnek át, jelezve, hogy feltehetően több pályaexplorációban és jövőtervezésben volt részük.

A tehetséges tanulók pályafejlődésével kapcsolatban az a nézet erősödött meg (Holland, 1997, Kerr és Colangelo, 1988, Kerr és Ghrist-Priebe, 1988, Emmet és Minor, 1993), hogy esetükben a képességek és az érdeklődés széles köre, multipotencialitása fokozott bizonytalanságot szül. Ugyanakkor Achter, Lubinski és Benbow (1996) elsőként cáfolták ezeket az elképzeléseket. Olyan 12-13 éves kiemelkedően tehetséges tanulókat vizsgáltak, akik a John Hopkins Egyetemen indított Matematikában Előrehaladott Fiatalok programban vettek részt. Azt találták, hogy a fiatalok jelentősé része (háromból egy diák) igencsak differenciált intellektuális képességekkel, pályaérdeklődéssel és értékekkel bír. Ha azonban csak a verbális és matematikai képességeket vették figyelembe, megmutatkozott a korábban feltételezett multipotencialitás. Értelmezésük szerint tehát nem multipotencialitásról van szó, hanem a jól teljesítők egyszerűen a mérhető szint tetejét érték el minden tantárgyból, azoknál pedig, akik alulteljesítenek, olyan differenciált az érdeklődés, hogy nem hajlandóak egyéb témákban gondolkodni. Milgram és Hong (1999) két középiskolai végzős mintán ( $\mathrm{N}=322$ és $\mathrm{N}=217$ ) kutatták a tehetségesek és a kiemelkedően tehetségesek képességeit és érdeklődését. Az izraeli hadsereg minden 11. és 12. osztályos tanulót felmér a kötelező katonai szolgálat előtt, $s$ közülük a kiemelkedő személyek (az országra vetítve 5\%) kerültek a mintába, mind fiúk. Verbális, matematikai, műszaki képességeket vizsgáló és a pályaérdeklődésre vonatkozó kérdéseket alkalmaztak. Vizsgálatuk szerint a tanulók 75\%-a mind a képességek, 
mind pedig az érdeklődés tekintetében differenciáltságot mutatott, sőt 40\%-uk az erősen differenciált kategóriába tartozott. A fiatalok között tehát található, de igen kis számban olyan, aki mutatja a multipotencialitás jeleit. Javaslatuk szerint a tehetséges fiatalokat eltérő csoportokként érdemes kezelni, mégpedig differenciált, nem specifikus és nem differenciált érdeklődésűekként, $s$ a pályatanácsadás során is eltérően kell kezelni az egyes csoportba tartozókat. 2001-ben Sajjadi, Rejskind és Shore szintén megerősítették, hogy a tehetséges fiúk érdeklődési profilja nem lapos, hanem erős kidolgozottságot mutat. A kutatások másik irányát az érdeklődési típusok, a nemek közötti különbségek és a természettudományos érdeklődés kialakítása adta. Többen rávilágítottak, hogy a tehetségként azonosított személyek erős kutató és gyakorlati, viszont alacsony szociális vonzódást mutattak, továbbá az utánkövetés stabil érdeklődési elrendeződést tárt fel (Vock, Köller és Nagy 2013, Sparfeldt, 2007), hasonlóan tipikus társaikhoz. Lubinski, Benbow és Ryan (1995) matematikában és fizikában jeleskedő egyének $(\mathrm{N}=162)$ longitudinális vizsgálatát végezte el. 13 és 28 éves korukban elemezték az érdeklődési profiljukat, és megállapították, hogy az intraindividuális korreláció 0.50 , vagyis igen korai életkorban is jól előrejelezhető az ember érdeklődési köre. A Holland-féle tipológiából a konvencionális típus a legváltozékonyabb meglátásuk szerint, ám a realista, a kutató és a művészi pályák iránti vonzalom tartós marad. Oppler és mtsai. (1993) kifejezetten arra hívták fel a figyelmet, hogy az általános iskola korai szakaszában fontos a tudományos pályákkal való ismerkedés, különösen a lányok esetében, még mielőtt a nemi szerepek felmerülnek. Kutatásukba hetedik osztályos tanulókat vontak be. A fiúk a hagyományosan férfidominanciát mutató területeket válogatták maguknak (például vegyészet, információ-technológia, mérnök), míg a lányok a tanári, tanácsadói és szociális tevékenységeket tartották megfelelőnek. Ugyanakkor ha az érdeklődés szintjét vesszük figyelembe, öt olyan foglalkozás is van, amely mindkét nem listáján előkelő helyen szerepel: cégvezető, orvos, ügyvéd, tudós és színész, s ezek azt mutatják, hogy bizonyos magasabb szintű foglalkozások iránt később csökken a tanulók - különösen a lányok - vonzalma. A tehetséggondozás alapvető feladata, hogy a legkiválóbb kapacitású fiatalokat megnyerje azoknak a pályáknak, ahol a felfedezés, az innováció és az irányítás teret kaphat. Kerr (1982, idézi Tóth, 1998) számolt be arról a programról, amelyben 11. osztályos tehetséges diákokat igyekeztek bátorítani az igényesebb pályák választására. A foglalkozás során az önismeret mellett egyetemeket és előadásokat látogattak a fiatalok, egyetemi oktatókkal és tanácsadókkal konzultáltak, egyéni és csoportos megbeszélésen vettek részt, ahol az eredményeiket megismerhették, és felvázolhatták jövőjüket. Azokra a diákokra külön is fókuszáltak a program vezetői, akik képességeik alatt, a nemi sztereotípiák szerint vagy alacsony státuszú foglalkozásokban gondolkodtak, s igyekeztek számukra hangsúlyozni a magas igényszint fontosságát. Több héttel a program után azt tapasztalták a kutatók, hogy a lányok igényszintje megnőtt, bátrabban választottak kvalifikáltabb munkákat, míg 
a fiúk igényszintje nem változott (hiszen már korábban is emelkedett szintet mutatott). Höffler, Köhler és Parchmann (2019) egy új eszköz, a RIASEC+N segítségével egyrészt azt igazolták, hogy a tehetséges fiúk - az elképzeléseknek megfelelően - inkább a kutató területet preferálják, míg a lányok a müvészi és szociális tudományokkal foglalkoznak szívesen, másrészt azok esetében magasabb a természettudományos terület iránti vonzódás, akik részt vettek már tudományos versenyeken. Vagyis az iskolai tudományos gazdagító programok és megmérettetések segítik a nemek közötti különbségek leküzdését, továbbá támogatják a fiúk szociális és művészi fejlődését, mely - értelmezésük szerint - a tudományos világban elengedhetetlen a kapcsolati háló fenntartásához. A tehetséges lányok tudományos előmenetelét nemcsak az iskolai programok, hanem a kulturális és anyai példaképek is befolyásolják, ahogy Fiebig és Beauregard (2010) bizonyította. Amerikai és német középiskolás lányok fejlődését követték a teljes iskolai szakasz során. Mindkét csoport magas kvalifikációt jelölt meg elérendő célként, ám az amerikai mintában szignifikánsan csökkent a diploma utáni vágy az iskola befejezésének időpontjában. A német lányok bátrabban vállalták fel a nem tradicionális pályákat, különösen akkor, ha az anya maga is ezt az utat járta be. Azaz nem az anya végzettségi szintje és karrierje volt a meghatározó, hanem hogy mit gondolt a társadalom nemi szerepeiről.

\section{Összegzés}

Sok idő telt el azóta, hogy a szakmák elkülönültek, egyre speciálisabb területeik megjelentek, mégis egyre inkább porondon van annak a kérdése, hogyan lehet úgy megtalálni az egyénhez leginkább illő pályát, hogy abban önmaga lehessen, ugyanakkor a társadalom és a munkaerőpiac felől érkező elvárásoknak is meg tudjon felelni.

Az évtizedes kutatások arra a következtetésre jutottak, hogy bár soktényezős feladatról van szó, de az érdeklődés kiemelt jelentőséggel bír benne. Az érdeklődés vonásjellegű preferencia, amely motivációs funkciót tölt be, érzelmi és kognitív válaszokkal meghatározza az egyén viselkedését. Egyes kutatók genetikai meghatározottságot sejtenek az érdeklődés mögött, mások a genetikán túlmenően fejlődési folyamatként írják le, mely egy kötődéssel indul az érdeklődés tárgya iránt, a kellemes érzés pedig arra serkenti az egyént, hogy több időt töltsön az adott tárggyal. Az érdeklődés nem állandó abban az értelemben, hogy a környezet - például egy új munkaterület - az adott tevékenységen belül átirányíthatja a figyelmet, illetve szélesítheti vagy szűkítheti az érdeklődést. Különösen az általános iskola és középiskola átmenetére jellemző, hogy a kompetenciák érésével, a képességek alakulásával a gyermekkorban kedvelt tevékenységek (rajzolás, állatok iránti vonzalom) elhalványulnak, s nem lesznek potenciális munkaterületekké. Azonban igen korai életszakaszban 
megfigyelhetők az érdeklődés főbb jellegzetességei, melyek közül a tárgyak versus emberek kettősség a legnyilvánvalóbb, majd pedig a nemek szerinti elkülönülés válik érzékelhetővé. A középiskola végére, illetve az egyetemi évek kezdetén stabilizálódik az érdeklődés mintázata, amely a kutatások szerint a következő két évtizedben megmarad.

A család és az egyéb személyes inputok, a rassz, nem, akadályozottság vagy az egészségügyi státusz a tanulási tapasztalaton keresztül hat az érdeklődésre. Kevés figyelem irányul azonban arra - különösen magyar vonatkozásban -, hogy az iskolai munka formálja-e a tanulók pályaérdeklődését direkt vagy indirekt módon. Hiányosak a kutatások bizonyos iskolatípusokra - például a gimnáziumokra -, illetve a speciális csoportokra vonatkozóan. A szakirodalom nem ad megnyugtató választ arra a kérdésre, milyen a 21. századi gimnazisták érdeklődése, van-e eltérés a nemek és a speciális csoportok pályaérdeklődése között. Nem ismert, mennyire differenciálódott a középiskolások pályák iránti vonzalma, illetve az érdeklődés intenzitásának van-e jelenősége a pályadöntés során. Nincs kellően feltárva az a terület, amely megmutatná, vajon az iskolai pályaedukációs munka vagy a tanulmányi eredmény befolyásolja-e a tanulók érdeklődésének formálódását, továbbá az sem egyértelmű, van-e kapcsolat a pályaérdeklődés és a pályaválasztási bizonytalanság szintje között.

Annyi bizonyos ugyanakkor, hogy az érdeklődés bizonyítottan hatással van a személyes, a tanulmányok és a munka világával kapcsolatos jóllétünkre. A személyiség lényeges részét reprezentálja, irányítja az egyén választásait, célvezérelt viselkedésre sarkall, energetizálja és fenntartja az erőfeszítést, amíg az ember el nem éri a kitűzött célt. Korábban az érdeklődés szerepe a teljesítmény elörejelzésében nem volt jelentős tényező, mert a képességek és a személyiség felülírta azt. Több metaanalízis és kutatás azonban bizonyította, hogy a jövőbeni teljesítmény és a sikeres karrier kitapintható az érdeklődés feltárásával.

A szakirodalom áttekintése rámutatott hiányosságokra és egyúttal lehetőségekre is. Az iskolai munka szempontjából az alábbi tanulságok vonhatók le:

- törekedni kell a tanulók érdeklődésének elsődleges feltárására,

- a legtöbb lehetőség megmutatásával formálni szükséges a pályák iránti attitűdöt,

- már a korai szakaszban érdemes kitapintani az érdeklődési irányokat,

- különösen a lányoknál fontos még a nemi szerepek elsajátítása elött a lehető legtöbb tevékenységbe bevonni őket,

- mindenfajta pályaedukációs tevékenységnek jelentősége és haszna van, de nem a formájuk és számuk a lényeges, hanem az intenzitásuk,

- vagyis a rendszeresség és folyamatos erősítés, a tantervbe való beépítettség számít,

- a gimnáziumi tanulókra ugyanolyan figyelmet érdemes szentelni, mint a középiskolába készülők esetében,

- az érettségi környékén megfigyelt érdeklődés várhatóan a következő két évtizedben meghatározó lesz, 
- az érdeklődés kiforrottsága növeli a tanulmányi eredményességet,

- továbbá csökkenti a pályaválasztással járó bizonytalanságot,

- a speciális tanulói csoportok eltérő fókuszú beavatkozást igényelnek, az SNI-tanulók önértékelését és énhatékonyságát kell fejleszteni, míg a tehetséges tanulók differenciált érdeklődését támogatni.

\section{Irodalomjegyzék}

Achter, J. A., Lubinski, D., \& Benbow, C. E (1996). Multipotentiality among the intellectually gifted: It was never there and already it's vanishing. Journal of Counseling Psychology, 43, 65-76. https://doi.org/10.1037/0022-0167.43.1.65

Ackerman, P. L., \& Heggestad, E. D. (1997). Intelligence, personality and interests: Evidence for overlapping traits. Psychological Bulletin, 121, 219-245.

https://doi.org/10.1037/0033-2909.121.2.219

Ainley, M. (2007). Being and feeling interested: Transient state, mood, and disposition. In P. Schutz (Ed.), Emotion in education (pp. 147-157). New York, NY: Academic Press. https://doi.org/10.1016/B978-012372545-5/50010-1

Allen, J., \& Robbins, S. (2010). Effects of interest-major congruence, motivation, and academic performance on timely degree attainment. Journal of Counseling Psychology, 57, 23-35. https://doi.org/10.1037/a0019085 https://doi.org/10.1037/a0017267

Almeida, P. I. L., Ahmetoglu, G., \& Chamorro-Premuzic, T. (2014). Who wants to be an entrepreneur? The relationship between vocational interests and individual differences in entrepreneurship. Journal of Career Assessment, 22(1), 102-112. https://doi.org/10.1177/1069072713492923

Atitsogbe, K. A., Moumoula, I. A., Rochat, S. Antonietti, J-P., Rossier, J. (2018.) Vocational interests and career indecision in Switzerland and Burkinae Faso: Crosscultural similarities and differences. Journal of Vocational Behavior. 126-140. https://doi.org/10.1016/j.jvb.2018.04.002

Betsworth, D. G., \& Fouad, N. A. (1997). Vocational interests: A look at the past 70 years and a glance at the future. Career Development Quarterly, 46, 23-47. https://doi.org/10.1002/j.2161-0045.1997.tb00689.x

Blažev, M., Babarović, T., Šverko, I. (2019). Changes in gender-stereotyped interests during the transition after high school. 43rd IAEVG International conference poster, Sept. 11-13. Bratislava

Borbély-Pecze T. B. (2010). Életút támogató pályaorientáció. Doktori dolgozat. ELTE PPK 
Borbély-Pecze T. B. - Fazakas I. - Juhász Á. (2019). Pályabolyongások - Pályaorientációról a Szakképzés 4.0 stratégia kapcsán, Új Pedagógiai Szemle, 7-8. 95-106.

Bouchard, T. J. (1997). Genetic influences on mental abilities, personality, vocational interests, and work attitudes. International Review of Industrial and Organizational Psychology, 12, 373-395.

Brown, S. D., Hacker, J., Abrams, M., Carr, A., Rector, C., Lamp, K., Telander, K., Siena, A. (2012). Validation of a four-factor model of career indecision. Journal of Career Assessment, 20:3-21. https://doi.org/10.1177/1069072711417154

Burns, S. T., Garcia, G. L., Smith, D. M., Goodman, S. R. (2016). Adding Career Biographies and Career Narratives to Career Interest Inventories. Journal of Employment Counseling, 53(3), 98-111. https://doi.org/10.1002/joec.12032

Ceci, S. J., Williams, W. M., Barnett, S. M. (2009). Women's underrepresentation in science: Sociocultural and biological considerations. Psychological Bulletin, 135, 218261. https://doi.org/10.1037/a0014412

Chamorro-Premuzic, T. (2015). Personality and individual differences. The British Psychologycal Society and Wiley.

Chamorro-Premuzic, T., A. Furnham and P.L. Ackerman (2006), "Ability and personality correlates of general knowledge", Personality and Individual Differences, Vol. 41/3, pp. 419-429. https://doi.org/10.1016/j.paid.2005.11.036

Chartrand, J. M., \& Robbins, S. B. (1990). Using multidimensional career decision instruments to assess career decidedness and implementation. The Career Development Quarterly, 39, 166-177. https://doi.org/10.1002/j.2161-0045.1990.tb00837.x

Creed, P., Patton, W., Prideaux, L.-A. (2006). Causal Relationship Between Career Indecision and Career Decision-Making Self-Efficacy: A Longitudinal Cross-Lagged Analysis. Journal of Career Development, 33(1):pp. 47-65.

https://doi.org/10.1177/0894845306289535

Crites, J. O. (1999). Operational definitions of interests. In M. L. Savickas, A. R. Spokane (Eds.), Vocational interests (pp. 163-170). Palo Alto, CA: Davies-Black.

Czeglédi E., Máth J. (2013). Az iskolai teljesítményt befolyásoló tényezők vizsgálata. Alkalmazott Pszichológia, 13(4):23-46.

Darcy, M. U. A., \& Tracey, T. J. G. (2007). Circumplex structure of Holland's RIASEC Interests across gender and time. Journal of Counseling Psychology, 54, 17-31. https://doi.org/10.1037/0022-0167.54.1.17

Denissen, J. J., Zarrett, N. R., \& Eccles, J. S. (2007). I like to do it, I'm able, and I know I am: Longitudinal couplings between domain-specific achievement, self-concept, and interest. Child Development, 78(2), 430-447.

https://doi.org/10.1111/j.1467-8624.2007.01007.x 
Di Fabio, A., Maree, J. G. (2013). Effectiveness of the career interest profile. Journal of Employment Counseling, 50(3), 110-123. https://doi.org/10.1002/j.2161-1920.2013.00030.x

Donnay, D. A. C., Morris, M. L., Schaubhut, N. A., \& Thompson, R. C. (2005). Strong Interest Inventory manual: Research, development, and strategies for interpretation. Mountain View, CA: CPP.

Donohue, R. (2006). Person-environment congruence in relation to career change and career persistence. Journal of Vocational Behavior, 68, 504-515.

https://doi.org/10.1016/j.jvb.2005.11.002

Duffy, R. D., \& Sedlacek, W. E. (2007). The presence of and search for a calling: Connections to career development. Journal of Vocational Behavior, 70, 590-601. https://doi.org/10.1016/j.jvb.2007.03.007

Emmett, J. D., \& Minor, C. W. (1993). Career decision-making factors in gifted young adults. Career Development Quarterly, 41, 350-366. https://doi.org/10.1002/j.2161-0045.1993.tb00409.x

Feldman, D. C. (2003). The antecedents and consequences of early career indecision among young adults. Human Resource Management Review, 13, 499-531.

https://doi.org/10.1016/S1053-4822(03)00048-2

Fiebig, J. N., Beauregard, E. (2010). Longitudinal Change and Maternal Influence on Occupational Aspirations of Gifted Female American and German Adolescents. Journal for the Education of the Gifted. Vol. 34, No. 1, pp. 45-67. https://doi.org/10.1177/016235321003400103

Finánczy E. (1932). Herbart: Pedagógiai előadások vázlata. Budapest: Kisdednevelés, 22.

Furnham, A., Monsen, J., Ahmetoglu, G. (2009). „Typical intellectual engagement, Big Five personality traits, approaches to learning and cognitive ability predictors of academic performance", British Journal of Educational Psychology, Vol. 79/4, pp. 769-782., https://doi.org/10.1348/978185409X412147

Gati, I., Krausz, M., \& Osipow, S. H. (1996). A taxonomy of career decision-making difficulties. Journal of Counseling Psychology, 43, 510-526.

https://doi.org/10.1037/0022-0167.43.4.510

Germeijs, V., De Boeck, P. (2002). A Measurement Scale for Indecisiveness and its Relationship to Career Indecision and Other Types of Indecision. European Journal of Psychological Assessment, Vol. 18, Issue 2, pp. 113-122. https://doi.org/10.1027//1015-5759.18.2.113

Gottfredson, L. S. (1981). Circumscription and compromise: A developmental Theory of occupational aspirations. Journal of Counseling Psychology, 28(6), 545-579. https:// doi.org/10.1037/0022-0167.28.6.545 
Gottfredson, L. S. (2005). Applying Gottfredson's theory of circumscription and compromise in career guidance and counseling. In S. D. Brown \& R. W. Lent (Eds.), Career development and counseling: Putting theory and research to work (pp. 71-100). Hoboken, NJ: John Wiley \& Sons.

Guay, F., Senécal, C., Gauthier, L., Fernet, C. (2003). Predicting Career Indecision: A Self-Determination Theory Perspective. Journal of Counseling Psychology, Vol. 50, No. 2, 165-177 https://doi.org/10.1037/0022-0167.50.2.165

Hansen, J. C. (1984). The measurement of vocational interests: Issues and future directions. In S. D. Brown \& R. W. Lent (Eds.), Handbook of counseling psychology (pp. 99-136). New York: Wiley.

Hárs, Á. - Tóth, G. (2009): A pályaorientációs / karrier tanácsadás gazdasági hatása, hatékonyságának és költségráforditásainak vizsgálata. Kutatási beszámoló. Kopint-Tárki.

Häussler, P., Hoffmann, L. (2002). An intervention study to enhance girls' interest, self-concept, and achievement in physics classes. Journal of Research in Science Teaching 39(9):870-888. https://doi.org/10.1002/tea.10048

Henry, P. (1989). Relationship between Academic Achievement and Measured Career Interest: Examination of Holland's Theory. Psychological Reports, 64(1), 3540. https://doi.org/10.2466/pr0.1989.64.1.35

Hidi, S., \& Renninger, K. A. (2006). The four-phase model of interest development. Educational Psychologist, 41(2), 111-127. https://doi.org/10.1207/s15326985ep4102_4

Hoff, K. A., Briley, D. A., Wee, C. J. M., \& Rounds J. (2018). Normative changes in interests from adolescence to adulthood: A meta-analysis of longitudinal studies. Psychological Bulletin. 426-451. https://doi.org/10.1037/bul0000140

Hoff, K. A., Song, Q. C., Einarsdóttir, S., Briley, D. A., \& Rounds, J. (2020). Developmental structure of personality and interests: A four-wave, 8-year longitudinal study. Journal of Personality and Social Psychology, 118(5), 10441064. https://doi.org/10.1037/pspp0000228

Holland, J. L. (1959). A theory of vocational choice. Journal of Counseling Psychology, 6(1), 35-45. https://doi.org/10.1037/h0040767

Holland, J. L. (1997). Making vocational choices (3rd ed.). Odessa, FL: Psychological Assessment Resources.

Höffler, T. N., Köhler, C. \& Parchmann, Ilka (2019). Scientists of the future: an analysis of talented students' interests. International Journal of STEM Education, $\mathrm{Vol}$ 6, 29. https://doi.org/10.1186/s40594-019-0184-1

Ion, A., Nye, C. D., \& Iliescu, D. (2017). Age and gender differences in the variability of vocational interests. Journal of Career Assessment, 27(1), 97-113.

https://doi.org/10.1177/1069072717748646 
Izard, C. E., Ackerman, B. P., Schoff, K. M. \& Fine, S. E. 1438. (2000). Self-organization of discrete emotions, emotion patterns, and emotion-cognition relations. In M. Lewis, \& I. Granic (Eds.), Emotion, development, and Self-organization. (pp. 15-36). New York: Cambridge University Press. https://doi.org/10.1017/CBO9780511527883.003

Kereszty Orsolya (2014): Nők az oktatásban Magyarországon 1989-2013, In: Juhász Borbála (szerk.) A nötlen évek ára: A nök helyzetének közpolitikai elemzése: 19892013. Magyar Női Érdekérvényesítő Szövetség, Budapest, 259-294.

Kerr, B. A., \& Colangelo, N. (1988). The college plans of academically talented students. Journal of Counseling and Development, 67, 42-48. https://doi.org/10.1002/j.1556-6676.1988.tb02009.x

Kerr, B. A., \& Ghrist-Priebe, S. (1988). Intervention for multipotentiality: Effects of a Career Counseling Laboratory for Gifted High School Students. Journal of Counseling and Development, 66, 366-369. https://doi.org/10.1002/j.1556-6676.1988.tb00888.x

Klapwijk, R., Rommes, E. (2009). Career orientation of secondary school students (m/f) in the Netherlands. Int J Technol Des Educ 19, 403-418.

https://doi.org/10.1007/s10798-009-9095-7

Köller, O., Baumert, J., \& Schnabel, K. (2001). Does Interest Matter? The Relationship between Academic Interest and Achievement in Mathematics. Journal for Research in Mathematics Education, 32(5), 448-470. https://doi.org/10.2307/749801

Krapp, A. (2002). An Educational-Psychological Theory of Interest and Its Relation to SDT In Deci, E. L., \& Ryan, R. M. (Eds.). (2002). Handbook of self-determination University of Rochester Press.

Krapp, A. (2007). An educational-psychological conceptualization of interest. International. Journal of Educational and Vocational Guidance, 7, 5-21. https://doi.org/10.1007/s10775-007-9113-9

Krause, J. S., \& Clark, J. M. R. (2014). Stability of vocational interests after recent spinal cord injury. Rehabilitation Psychology, 59, 321-328. https://doi.org/10.1037/a0037265

Lawson, K. M., Leeb, B., Crouter, A. C., \& McHale, S. M. (2018). Correlates of gendered vocational development from middle childhood to young adulthood. Journal of Vocational Behavior, 107, 209-221. https://doi.org/10.1016/j.jvb.2018.05.002

Lee, W., Lee, M-J., Bong, M. (2014). Testing interest and self-efficacy as predictors of academic self-regulation and achievement. Contemporary Educational Psychology, Vol 39, Issue 2, 86-99. https://doi.org/10.1016/j.cedpsych.2014.02.002

Lindstrom, L., Harwick, R. M., Poppen, M., \& Doren, B. (2012). Gender Gaps: Career Development for Young Women With Disabilities Career Development and Transition for Exceptional Individuals. Career Development for Exceptional Individuals, 20 (10), 1-10. 
Low, K. S. D., Yoon, M., Roberts, B. W., \& Rounds, J. (2005). The stability of vocational interests from early adolescence to middle adulthood: A quantitative review of longitudinal studies. Psychological Bulletin, 131, 713-737.

https://doi.org/10.1037/0033-2909.131.5.713

Lubinski, D. (2000). Scientific and social significance of assessing individual differences: „Sinking shafts at a few critical points.” Annual Review of Psychology, 51, 405-444. https://doi.org/10.1146/annurev.psych.51.1.405

Lucas, M. S. (1993). A validation of types of career indecision at a counseling center. Journal of Counseling Psychology, Vol. 40. No. 4., 440-446.

https://doi.org/10.1037/0022-0167.40.4.440

Ludwikowski, W. M. A., Scheshinger, H. A., Armstrong, P. I. (2019). Are Interest Assessments Propagating Gender Differences in Occupations? Journal of Career Assessment, pp. 14-27. https://doi.org/10.1177/1069072718821600

Lukács É. F. (2012). A pályaválasztás és identitásfejlödés összefüggései. Doktori dolgozat. ELTE PPK.

Maree, J. G. (2019). Group Career Construction Counseling: A Mixed-Methods Intervention Study With High School Students. Career Development Quarterly, 67(1), 47-61. https://doi.org/10.1002/cdq.12162

Milgram, R. M., \& Hong, E. (1999). Multipotential abilities and vocational interests in gifted adolescents: Fact or fiction? International Journal of Psychology, 34(2), 81-93. https://doi.org/10.1080/002075999399981

Mustata, A.-E. (2014). The role of gender in the formation of vocational interests and career orientation in adolescence. Procedia - Social and Behavioral Sciences, 127, 240-244. https://doi.org/10.1016/j.sbspro.2014.03.248

Noack, P., Kracke, B., Gniewosz, B., \& Dietrich, J., (2010). Parental and school effects on students' occupational exploration, Journal of Vocational Behavior, 77(1), 50-57. https://doi.org/10.1016/j.jvb.2010.02.006

Nye, C. D., Su, R., Rounds, J., \& Drasgow, F. (2012). Vocational interests and performance: A quantitative summary of over 60 years of research. Perspectives on Psychological Science, 7(4), 384-403.

https://doi.org/10.1177/1745691612449021

Ochnik, D., Arzenšek, A. (2020). Vocational interests among Polish and Slovenian students of management. Journal of the Higher School of Economics. Vol. 17. N 2. P. 328-344. https://doi.org/10.17323/1813-8918-2020-2-328-344

Oppler, S. H., Stocking, V. B., Goldstein, D., Porter, L. C. (1993). Career Interests of Academically Talented Seventh Graders. American Institutes for Research, Washington Office Duke University Talent Identification Program. Paper presented 
at the Annual Meeting of the American Educational Research Association, Atlanta, Georgia, April 12-16.

Osipow, S. H. (1999). Assessing career indecision. Journal of Vocational Behavior: Special Issue on Holland's Theory, 55, 147-154. https://doi.org/10.1006/jvbe.1999.1704

Ostorics L., Szalay B., Szepesi I., Vadász Cs. (2016). PISA 2015 Összefoglaló jelentés. Oktatási Hivatal, Budapest.

Ott-Holland, C. J., Huang, J. L., Ryan, A. M., Elizondo, F., \& Wadlington, P. L. (2013). Culture and vocational interests: The moderating role of collectivism and gender egalitarianism. Journal of Counseling Psychology, 60(4), 569-581.

https://doi.org/10.1037/a0033587

Päessler, K. (2015). Sex differences in the variability of vocational interests. European Journal of Personality, 29, 568-578. https://doi.org/10.1002/per.2010

Pusztai G., Szigeti F. (szerk.) (2018). Lemorzsolódás és perzisztencia a felsöoktatásban. Debrecen, Debreceni Egyetemi Kiadó.

Rawat, A. (2011). Examining work as calling. Doktori dolgozat. University of Pittsburgh. Renninger, K. A., Hidi, S., \& Krapp, A. (1992). The role of interest in learning and development. Hillsdale, NJ: Erlbaum.

Réti M. (2010 vagy 2011): Nemi szerepek és tanulás. Magyar Tudomány, 2. 234-242.

Ritoók P. (1986). Személyiségfejlesztés és pályaválasztás. Budapest, Tankönyvkiadó.

Roberts, B. W., \& DelVecchio, W. F. (2000). The rank-order consistency of personality from childhood to old age: A quantitative review of longitudinal studies. Psychological Bulletin, 126, 3-25. https://doi.org/10.1037/0033-2909.126.1.3

Roberts, B. W., \& Wood, D. (2006). Personality development in the context of the Neo-Socioanalytic Model of Personality. In D. K. Mroczek \& T. D. Little (Eds.), Handbook of personality development (pp. 11-39). Mahwah, NJ: Erlbaum.

Roberts, B. W., Walton, K. E., \& Viechtbauer, W. (2006). Patterns of mean-level change in personality traits across the life course: A meta-analysis of longitudinal studies. Psychological Bulletin, 132(1), 1-25. https://doi.org/10.1037/0033-2909.132.1.1

Rohe, D. E. \& Krause, J. S. (1998). Stability of interests after severe physical disability: An 11-year longitudinal study. Journal of Vocational Behavior, 52, 45-58. https://doi.org/10.1006/jvbe.1996.1560

Rounds, J. (1995). Vocational interests: Evaluating structural hypotheses. In D. J. Lubinski \& R. V. Dawis (Eds.), Assessing individual differences in human behavior: New concepts, methods, and findings (pp. 177-232). Palo Alto, CA: Davies-Black Publishing.

Rounds, J., \& Su, R. (2014). The nature and power of interests. Current Directions in Psychological Science, 23(2), 98-103. https://doi.org/10.1177/0963721414522812 
Sadler, P. M., Sonnert, G., Hazari, Z., Tai, R. (2012): Stability and volatility of STEM career interest in high school: A gender study. Science Education, 96/3. 411-427. https://doi.org/10.1002/sce.21007

Sajjadi, S. H., Rejskind, F. G., \& Shore, B. M. (2001). Is multipotentiality a problem or not? A new look at the data. High Ability Studies, 12, 27-43.

https://doi.org/10.1080/13598130124556

Savickas, M. L., \& Spokane, A. R. (Eds.) (1999). Vocational interests. Palo Alto, CA: Davies-Black.

Schiefele, U. (2009). Situational and individual interest. In K. R. Wenzel \& A. Wigfield (Eds.), Educational psychology handbook series. Handbook of motivation at school (pp. 197-222). New York, NY, US: Routledge/Taylor \& Francis Group.

Schiefele, U., Krapp, A., \& Schreyer, I. (1993). Metaanalyse des Zusammenhangs von Interesse und schulischer Leistung. Zfitschriftfur Entwicklungspsychologie und Pddagogische Psychologie, 25, 120-148.

Schiefele, U., Krapp, A., \& Winteler, A. (1992). Interest as a predictor of academic achievement: A meta-analysis of research. In K. A. Renninger, S. Hidi, \& A. Krapp (Eds.), The role of interest in learning and development (pp. 183-212). Hillsdale, NJ: Erlbaum.

Schmidt, F. L. (2014), „A general theoretical integrative model of individual differences in interests, abilities, personality traits, and academic and occupational achievement: a commentary on four recent articles", Perspectives on Psychological Science, Vol. 9/2, pp. 211-218., https://doi.org/10.1177/1745691613518074

Silvia, P. J. (2001). Interest and interests: The psychology of constructive capriciousness. Review of General Psychology, 5(3), 270-290.

https://doi.org/10.1037/1089-2680.5.3.270

Silvia, P. J. (2006). Exploring the psychology of interest. New York, NY: Oxford University Press. https://doi.org/10.1093/acprof:oso/9780195158557.001.0001

Silvia, P. J. (2008). Interest - The curious emotion. Current Directions in Psychological Science, 17(1), 57-60. https://doi.org/10.1111/j.1467-8721.2008.00548.x

Sparfeldt, J. R. (2007). Vocational interests of gifted adolescents. Personality and Individual Differences Vol 42, Issue 6, 1011-1021.

https://doi.org/10.1016/j.paid.2006.09.010

Stǎricǎ, E. C. (2012). Predictors for career indecision in adolescence. Procedia - Social and Behavioral Sciences, 33 168-172. https://doi.org/10.1016/j.sbspro.2012.01.105

Stromberg, C. A., (2008). Career aspirations: Similarities and differences between adolescence with learning disabilities and adolescence not receiving special education services. Doktori dolgozat, Rochester Institute of Technology. 
$\mathrm{Su}, \mathrm{R}$. (2012). The power of vocational interests and interest congruence in predicting career success. Doktori dolgozat, University of Illinois at Urbana-Champaign.

Su, R., \& Nye, C. D. (2017). Interests and person-environment fit: A new perspective on workforce readiness and success. In J. Burrus, K. D. Mattern, B. Naemi, \& R. D. Roberts (Eds.), Building better students: Preparation for the workforce. New York: Oxford University Press. https://doi.org/10.1093/acprof:oso/9780199373222.003.0008

Su, R., Rounds, J., \& Armstrong, P. I. (2009). Men and things, women and people: A meta-analysis of sex differences in interests. Psychological Bulletin, 135, 859-884. https://doi.org/10.1037/a0017364

Su, R., Stoll, G., \& Rounds, J. (2019). The nature of interests: Toward a unifying theory of traitsituationinterest dynamics. In Christopher D. Nye \& J. Rounds (Eds.), Vocational Interests: Rethinking Their Role in Understanding Workplace Behavior and Practice. Taylor \& Francis/Routledge.

Suhajda Cs. J. (2017). A pályaorientációs tevékenység változása és megvalósulása a köznevelésben a rendszerváltozástól napjainkig különös tekintettel az információs folyamatokra. Doktori dolgozat, Pécsi Tudományegyetem.

Super, D. E. (1963). Self-concepts in vocational development. In D. E. Super, R. Starishevsky, N. Matlin, \& J. P. Jordaan (Eds.), Career development: Self-concept theory (pp. 1-16). New York, NY: College Entrance Examination Board.

Super, D. E. (1995). Values: Their nature, assessment, and practical use. In D. E. Super $\&$ B. Sveko (Eds.), Life roles, values, and the careers: International findings of the Work Importance Study (pp. 225-240). San Francisco: Jossey-Bass.

Szabó M., Kiss, I., Herczegné Keresztúri J., Szemán D., Czigány L. (é. n.). A pályatanácsadás hatékonyságmérésének lehetséges indikátorai. Kutatási beszámoló. http://eletpalya.munka.hu/c/document_library/get_file?uuid=327a69bf-c97d-45498d57-dd2ac8431234\&groupId=10418 (Utolsó letöltés: 2021. február 17.)

Szilágyi Klára (1997): Az egyéni tanácsadás. Módszertani kézikönyv a munkavállalási, munka-, pályatanácsadók számára. Gödöllői Agrártudományi Egyetem Gazdaságés Társadalomtudományi Kar Tanárképző Intézete, Gödöllő.

Tóth L. (szerk.) (1998): A tehetségek tanítása. Debrecen, Kossuth Egyetemi Kiadó.

Török, R. (2016). A pályadöntési énhatékonyság sajátosságai és változási mintázatai sajátos nevelési igényü és tipikus fejlödésü középiskolások körében. Doktori dolgozat, ELTE PPK.

Tracey, T. J. G. (2002). Development of interests and competency beliefs: A one-year longitudinal study of fifth to eighth grade students using the ICA-R and structural equation modeling. Journal of Counseling Psychology, 49, 148-163.

https://doi.org/10.1037/0022-0167.49.2.148 
Tracey, T. J. G., Robbins, S. B., \& Hofsess, C. D. (2005). Stability and change in interests: A longitudinal study of adolescents from grades 8 to 12. Journal of Vocational Behavior, 66, 1-25. https://doi.org/10.1016/j.jvb.2003.11.002

Tracey, T. J. G., \& Ward, C. C. (1998). The structure of children's interests and competence perceptions. Journal of Counseling Psychology, 45, 290-303. https://doi.org/10.1037/0022-0167.45.3.290

Tudlik Cs. (2020): A pályaérdeklődés kapcsolata a pályaválasztási bizonytalansággal és a karrierdöntési én-hatékonysággal. OxIPO, 2020/3, 43-54. https://doi.org/10.35405/OXIPO.2020.3.43

Turner, S. A., Jr., \& Silvia, P. J. (2006). Must things be pleasant? A test of competing appraisal structures. Emotion, 6(4), 670-674. https://doi.org/10.1037/1528-3542.6.4.670

Valla, J. M., Ceci, S. J. (2011). Can sex differences in science be tied to the long reach of prenatal harmones? Brain organization theory, digit ratio $(2 \mathrm{D} / 4 \mathrm{D})$, and sex differences in preferences and cognition. Perspectives on Psychological Science, 6, 134-146. https://doi.org/10.1177/1745691611400236

Van Iddekinge, C. H., Putka, D. J., \& Campbell, J. C. (2011). Reconsidering vocational interests for personnel selection: The validity of an interest-based selection test in relation to job knowledge, job performance, and continuance intentions. Journal of Applied Psychology, 96, 13-33. https://doi.org/10.1037/a0021193

Vardarlı, B., Özyürek, R., Wilkins-Yel, K. G., \& Tracey, T. J. G. (2017). Examining the structure of vocational interests in Turkey in the context of the personal globe model. International Journal for Educational and Vocational Guidance, 17, 347-359. https://doi.org/10.1007/s10775-016-9338-6

Vock, M., Köller, O., \& Nagy, G. (2013). Vocational interests of intellectually gifted and highly achieving young adults. British Journal of Educational Psychology, 83, 305328. https://doi.org/10.1111/j.2044-8279.2011.02063.x

Volodina, A., \& Nagy, G. (2016). Vocational choices in adolescence: The role of gender, school achievement, self-concepts, and vocational interests. Journal of Vocational Behavior, 95, 58-73. https://doi.org/10.1016/j.jvb.2016.07.005

Von Stumm, S., B. Hell and T. Chamorro-Premuzic (2011), "The hungry mind: intellectual curiosity ss the third pillar of academic performance", Perspectives on Psychological Science, Vol. 6/6, pp. 574-588, https://doi.org/10.1177/1745691611421204

Vroom, V. H., \& Deci, E. L. (1992). Management and motivation (2nd ed.). London, England: Penguin. 
Webb, R. M., Lubinski, D., \& Benbow, C. P. (2002). Mathematically facile adolescents with math-science aspirations: New perspectives on their educational and vocational development. Journal of Educational Psychology, 94, 785-794.

https://doi.org/10.1037/0022-0663.94.4.785

Whiston, S. C., Li, Y., Goodrich, M. N., Wright, L. (2017). Effectiveness of career choice interventions: a meta-analytic replication and extension. Journal of Vocational Behavior 100:175-184. https://doi.org/10.1016/j.jvb.2017.03.010

Wille, B., Tracey, T. J., Feys, M., \& De Fruyt, F. (2014). A longitudinal and multi-method examination of interest-occupation congruence within and across time. Journal of Vocational Behavior, 84(1), 59-73.

https://doi.org/10.1016/j.jvb.2013.12.001

\section{Jogszabály}

A nemzeti köznevelésről szóló 2011. évi CXC. törvény 